

DEN NORSKE LEGEFORENING

\title{
Færre kalorier gir bedre hukommelse
}

\author{
RETTELSE
}

ÅSLAUG HELLAND

Tidsskr Nor Legeforen 2009; 129: 611

I Tidsskriftet nr. 7/2009, på side 611, i midtspalten skal riktig ordlyd være: «Epidemiologiske undersøkelser har vist at høy kroppsmasseindeks midt i livet korrelerer med høyere prevalens av Alzheimers sykdom sent i livet.»

Publisert:30. april 2009. Tidsskr Nor Legeforen. DOI: 10.4045/tidsskr.09.0436

(C) Tidsskrift for Den norske legeforening 2023. Lastet ned fra tidsskriftet.no 26. april 2023. 